\title{
PRODUCTIVITY DIFFERENCES AND AGGLOMERATION ACROSS DISTRICTS OF GREAT BRITAIN
}

\section{Lubomira Anastassova}
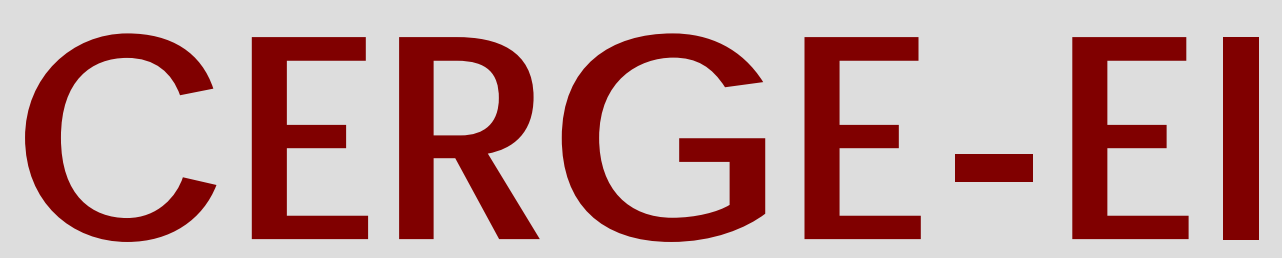

Charles University Centerfor Economic Research and Graduate Education Academy of Sciences of the Czech Republic Ec onomic Institute 


\section{Working Paper Series \\ 289 \\ (ISSN 1211-3298)}

\section{Productivity Differences and Agglomeration Across Districts of Great Britain}

Lubomira Anastassova

CERGE-EI

Prague, February 2006 
ISBN 80-7343-084-3 (Univerzita Karlova v Praze, CERGE)

ISBN 80-7344-073-3 (Národohospodářský ústav AV ČR, Praha) 


\title{
Productivity Differences and Agglomeration Across Districts of Great Britain*
}

\author{
Lubomira Anastassova ${ }^{\Theta}$
}

CERGE-EI**

\begin{abstract}
This paper examines the impact of employment density (agglomeration) on the hourly earnings of workers across districts of Great Britain. The potentially two-way causality between agglomeration and productivity is dealt with using two instruments: the total land area of a district and its population density. The estimated agglomeration effect is similar across different levels of territorial aggregation; however, the effect is stronger when looking only across Metropolitan areas. There is evidence of endogeneity only when the sample is split into Metropolitan and Non-Metropolitan areas and even so endogeneity has only little effect on the estimates.
\end{abstract}

\begin{abstract}
Abstrakt
Tato studie se zabývá dopadem hustoty zaměstnanosti (aglomerací) na hodinové výdělky pracovníků v okresech Velké Británie. Potenciální dvoucestná kauzalita mezi aglomerací a produktivitou je šetřena pomocí dvou instrumentů: celkové velikosti území daného okresu a jeho hustotou obyvatelstva. Odhadnutý aglomerační efekt je podobný mezi rozdílnými úrovněmi teritoriální agregace. Přesto se dá říci, že efekt je silnější pokud uvažujeme pouze metropolitní území. Endogenita je prokázána pouze za předpokladu že je vzorek rozdělen na metropolitní a nemetropolitní území. Dalším zjištění je, že endogenita má pouze malý vliv na odhady.
\end{abstract}

JEL Classification: C31, O18, R12

Keywords: Agglomeration, Productivity, Multiple Instruments

\footnotetext{
* I would like to thank Štěpán Jurajda, Randall Filer and Alexandru Chirmiciu for their valuable suggestions and comments.

${ }^{\Theta}$ Email: Lubomira.Anastassova@cerge-ei.cz.

** A joint workplace of the Center for Economic Research and Graduate Education, Charles University, and the Economics Institute of the Academy of Sciences of the Czech Republic.

Address: CERGE-EI, P.O. Box 882, Politických vězňů 7, Prague 1, 11 21, Czech Republic
} 


\section{Introduction}

Regional policies are among the most challenging tasks for policy makers since regional differences within countries are often large and usually persistent. In developed countries, average labour productivity or workers' income in the richest regions is almost double that of the poor regions. The discrepancies are even higher in developing countries. ${ }^{1}$ Understanding the fundamental causes of these persistent inequalities is crucial in designing effective regional policies.

A key culprit among the possible explanations for regional differences in average labour productivity is the existence of spatial externalities and other sources of increasing returns such as transportation and coordination costs. Ciccone and Hall (1996) is the first study to empirically examine the effects of such spatial externalities and increasing returns. They capture agglomeration by using employment density which is defined as the number of people employed per square kilometer. ${ }^{2}$ In a world with constant returns to capital, where transportation costs are negligible due to well-developed infrastructure, employment density is a potential source of increasing returns resulting from stronger knowledge and technological spillovers in areas of dense economic activity.

The fundamental problem with the estimation of agglomeration effects on average labour productivity stems from the fact, that it is difficult to determine the causality of the

\footnotetext{
${ }^{1}$ For a detailed description of the regional income differences within a number of countries see Aten and Heston (2003).

${ }^{2}$ The terms agglomeration and employment density will be used interchangeably throughout the paper.
} 
observed positive correlation between the two. The presence of endogeneity is plausible since productivity or income can increase due to higher employment density as explained above, but it is also possible that higher productivity and wages may attract more workers and firms to a given area. Such reverse-causality can lead to overestimating of the effect of agglomeration on productivity and therefore should be carefully addressed.

There is extensive empirical literature on agglomeration-productivity relationship based on US data, ${ }^{3}$ and more recently a number of empirical studies on European countries. ${ }^{4}$ These studies estimate an elasticity of the average labour productivity with respect to the employment density in the range of 0.02 to 0.05 . The usual geographic level of analysis is county level (NUTS 3), and all existing studies use a maximum of one variable to instrument for employment density. Thus, the literature leaves several important questions to be answered such as what is the optimal geographic level at which the analysis should be conducted or how can agglomeration be best instrumented. My goal in this paper is to shed more light on the mechanism of the agglomeration effects by comparing results based on different levels of spatial division - NUTS 3 (county level) vs. NUTS 4 (district level), where a county is composed of more than one district. Furthermore, this study extends the existing literature by instrumenting for employment density simultaneously with two

\footnotetext{
3 See Rosenthal and Strange (2001) for the determinants of agglomeration and thorough analysis of agglomeration different geographic levels. See also Moomaw (1985), Henderson (1986) and the survey provided by Rosenthal and Strange (2004).

${ }^{4}$ Ciccone (2002), Combes et al. (2004), Duranton and Monastiriotis (2002), Kanbur and Venables (2003).
} 
variables, which provides higher precision of estimates and is also important in the light of the current local average treatment effect (LATE) literature. ${ }^{5}$

Specifically, this paper uses UK local authority district level (LAD) data provided by the Official Labour Market Statistics for the years 1998 and 2003. The analysis covers districts in England, Wales and Scotland, countries which are known for their large regional diversity and income differences. ${ }^{6}$ I adopt the specification used by Hall and Ciccone (1996) and Ciccone (2002), and examine the effect of agglomeration (employment density) on the average gross weekly earnings of UK workers across these districts.

The total land area of districts and the population density which prevailed across districts in 1801 are used as instruments. Both types of instruments are commonly used in the existing literature (Ciccone, 2002; Rice and Venables, 2004; Combes et al., 2004) since they are correlated to the employment density but not to productivity or income. However, all the studies use the above instruments separately, while I instrument agglomeration using jointly the total land area and the population density across regions. Furthermore, I also distinguish between Metropolitan and non-Metropolitan areas in an attempt to see whether the observed differences in productivity are driven mainly by the big cities and in particular by London. ${ }^{7}$ Finally, unlike most other studies, this paper provides rigorous testing of the

${ }^{5}$ Different instruments give different estimates since they weight the potentially heterogeneous effects across the population differently - more weight is given to those individuals for whom the given instrument has more predictive power (Angrist and Imbens, 1995).

${ }^{6}$ See Blackaby and Murphy (1995), Monastiriotis (2004), Rice and Venables (2004) .

${ }^{7}$ The focus of many agglomeration studies in the past has been on the potential relationship between city size and productivity (Moomaw, 1985; Henderson, 1986). These studies cover the US but suffer from output measurement error due to census miscalculation. Currently, the issue of size-specific agglomeration effects has gained popularity again (Strange, 2003). 
validity of the employed instruments and the presence of endogeneity using various specification tests.

The findings of the paper are generally in accordance with the existing research, since the estimated elasticity of hourly earnings with respect to employment density is about 4 percent and there is no major difference between the district and county-level results. The agglomeration effects in Metropolitan cities are significantly higher than those exhibited by both non-Metropolitan areas and the sample as a whole. The endogeneity issue seems not to be relevant in the pooled sample, but appears once Metropolitan areas and nonMetropolitan areas are considered separately.

\section{Empirical Background}

The theoretical foundation of the recent literature on agglomeration (approximated by density) is provided by Ciccone \& Hall (1996), who consider density as a source of aggregate increasing returns and define it as the intensity of labour, human and physical capital relative to physical space. Their paper finds a positive relationship between productivity at the state level and county employment density (agglomeration) across US states. Data on gross state output show that doubling of the employment density would raise the average labour productivity by 6 percent while differences in employment density explain more than half of the variance in output per worker across states. 
The search for answers regarding the determinants of productivity in the U.S proceeds with Rosenthal \& Strange (2001), who carry out an analysis of industries at three different aggregation levels: the zip code, county and state levels. The authors claim that agglomeration is positively affected by manufacturing inputs, shipping costs and natural resources on the state level, but these have little relevance at lower geographical levels. They conclude that labour market pooling has the most robust positive effect on agglomeration.

Since regional policies in the European Union prove to be one of the most disputed and controversial issues, there is growing empirical research on the causes of EU regional inequalities. Ciccone (2002) examines five European economies (France, Germany, Italy, Spain and the UK) and estimates the effects of agglomeration on spatial differences of income measured by value added per worker. The author analyses NUTS 3 regional incomes and points out the problem of endogeneity between productivity and agglomeration. He offers two solutions to this problem: the introduction of regional fixedeffects, and the use of regional total land-area as an instrument for employment density. The estimates of the elasticity of average-labour productivity with respect to agglomeration are close to 0.045 for all countries subject to his analysis.

Based on the premise that wage inequalities can result from regional differences in skills, non-human endowments or local interactions, Combes et al. (2004) search for the most plausible explanation supported by data. They use a large panel of French workers for the period 1976-1996, and find that the elasticity of earnings with respect to employment 
density is 0.02 . The endogeneity problem is addressed by instrumenting the employment density using the regional population density in 1936. These findings are in full accordance with the existing literature which claims that the interaction effects that result in increasing returns are mostly due to local employment density.

The authors argue that skills matter (highly-skilled workers who concentrate in highly dense populated areas get accordingly higher wages) and find strong evidence of spatial sorting by skills. The role of education in explaining regional inequalities is also confirmed by Duranton and Monastiriotis (2002) who find big discrepancies in the average regional earnings in the UK, which are accounted for mainly by differences in regional education.

Rice and Venables (2004) focus on regional income inequalities and their determinants. The authors consider the NUTS 3 sub-regions of Great Britain and explore the hypothesis that the proximity to economic mass, measured by driving time between regions, raises earnings. They confirm their hypothesis and find that the impact on productivity is the highest for economic centers within 40 minutes driving time. An alternative hypothesis under scrutiny is that the spatial variation of earnings is due to exogenously determined spatial characteristics such as the population size. In order to avoid the endogeneity bias stemming from the size of the current population inhabiting the counties of Great Britain and their average earnings, the authors instrument for it using the population of the NUTS 3 area in 1851. 
In this paper I also use UK regional data to study agglomeration effects, but contrary to Rice and Venables (2004), the main geographic unit of analysis in this paper is not county but district level. Agglomeration here is defined as employment density while Rice and Venables (2004) use the proximity of economic mass measured by travel time to economic areas. Another distinctive feature of this paper is that agglomeration is not instrumented by one instrument as usual, but by two alternative instruments: total land area of the district and the population density of a district in 1801. This allows for higher precision of estimates since the two instruments give different weights to the population depending on their predictive power. The district population density goes back to 1801 i.e. 50 years earlier than the population density used by Rice and Venables. This is an important distinction with regards to the exogeneity of the potential instrument, since population density in 1801 (long before the industrial revolution took place in Great Britain) is less likely to be correlated to productivity than population density in 1851 . The second main difference with regards to the existing agglomeration studies is that the sample is split into Metropolitan areas (greater London and the metropolitan counties) and non-Metropolitan areas since Metropolitan areas are more densely populated than the rest of the counties.

\section{Theoretical Background}

Extending the model of Ciccone and Hall (1996), Ciccone (2002) develops a theoretical model which is used to motivate the empirical estimates in this study. One of the assumptions of the model is that the density of economic activity is the source of spatial externalities responsible for average labour productivity differences across regions. 
According to Ciccone (2002), in order to have a meaningful measure of the density of economic activity, one should estimate externalities at a 'fine level of geographic details'. Therefore, in my analysis, I use regional data at the lowest possible geographic level (NUTS 4). One of the main disadvantages of working at this level is that there is no information of the quantity of physical capital across regions. Therefore, another important assumption of the model is that the rental price of capital is equal across large regions (here counties or bigger regions) which helps to overcome the problem with the missing data on the quantity of physical capital at such a detailed geographic level. ${ }^{8}$

The estimation of agglomeration effects using regional data stems from the following definition of the production function on an acre of land in region s, which belongs to a country or larger region c:

$q=\Omega_{s c} f\left(n H, k, Q_{s c}, A_{s c}\right)$

where $q$ is the output per acre of land, $n$ is the number of workers employed on the acre, $\mathrm{H}$ the average level of human capital of workers on the acre, and $k$ the amount of physical capital used on the acre; $\Omega_{s c}$ is the index of total factor productivity in the region; $Q_{s c}$ and $A_{s c}$ stand for the total production and total acreage in the region. The density of production $Q_{s c} / A_{s c}$ represents the spatial externality associated by physical proximity. The model is developed further (see Ciccone, 2002) and as a result the estimation equation at the regional level is given by

\footnotetext{
${ }^{8}$ See Ciccone (1996) and Ciccone (2002) for a detailed derivation of the rental capital price assumption.
} 
$\log Q_{s c}-\log N_{s c}=$ Large Region Dummies $+\theta\left(\log N_{s c}-\log A_{s c}\right)+\sum_{e=1}^{E_{c}} \delta_{e c} F_{e s c}+u_{s c}$

where $N_{s c}$ is the total employment in the region; $E_{c}$ is the number of different education levels existing in the large region $\mathrm{c} ; \delta_{e c}$ is the effect of the education level $e$ on the productivity in large region $\mathrm{c} ; F_{\text {esc }}$ is the fraction of employed people with certain type of education in region $\mathrm{s}$ in large region $\mathrm{c}$ and $u_{s c}$ captures the differences between total factor productivity in region $S C$ and a larger region. ${ }^{9}$

The left-hand side of equation (1) represents the logarithm of the output or earnings per worker in a region and the term $\log \left(N_{s c} / A_{s c}\right)$ is the $\log$ employment density or the agglomeration variable showing the number of workers employed per square kilometer. The higher region dummies in my case represent dummies of the regions in Great Britain.

\section{Data and Descriptive Analysis}

This study is based on data available from the Official Labour Market Statistics in the UK. ${ }^{10}$ The unit of analysis is the Local Authority District (LAD) which corresponds to NUTS 4 level and covers districts in England, Wales and Scotland. The basic building block for these areas is the electoral ward/division. The years subject to analysis are 1998 and 2003. 
The usual practice in estimating differences in productivity is to look at the gross value added per worker across regions. The UK National Labour Market Statistics do not offer data on value added at district level and although it could be approximated by different measures, it would still have the disadvantage that within small areas it is highly sensitive to local profits allocation and other non-wage income. In competitive labour markets, such as Great Britain, differences in earnings are expected to reflect differences in productivity. Therefore, in the analysis I focus on another commonly used variable - regional weekly earnings of full-time employees. The gross weekly earnings are taken from The New Earnings Survey, which is an annual survey based on 1 percent sample of employees in employment excluding the self-employed workers. ${ }^{11}$

Agglomeration is measured by employment density which equals the average number of full-time employed workers per square kilometer in a given district. Education is one of the most important characteristics to control for when studying wage differences. The data on education comes from regional Labour Force Surveys and covers the percentage of economically active workers with different types of education: NVQ4, NQV3, NQV2, NQV1, trade apprenticeships, other and no qualifications. I have grouped the educational

\footnotetext{
${ }^{9}$ See Ciccone (2002) and Ciccone and Hall (1996) for a detailed derivation of the estimated equation.

${ }^{10}$ See www.nomisweb.co.uk where Nomis is a web-based database of labour market statistics.

11 The total payments made to the employee for a weekly pay-period before any statutory or other deductions. They include all payments which related to that period regardless of when particular payments within the total were made or whether they were all paid at the same time. Where bonuses or similar payments are not paid in each pay-period, they include the proportionate amount for the reported pay-period based on the last payment, or next payment if known (for example, one-quarter of a monthly bonus for a weekly pay-period).
} 
levels in three groups: high education (NQV4 and NQV3), low education (NQV2, NQV1, trade apprenticeships and other qualifications) and no formal qualifications. ${ }^{12}$

The data is cross-sectional and consists of the two time periods of 1998 and 2003, because this reflects the possible change in the size of the effect of agglomeration and education on regional wages over time. There are 406 districts in the data but some of them have a very small territory and therefore had to be aggregated in accordance with the districts in the British Household Panel Survey and thus the number of districts decreased to 304. For the sake of comparative analysis at different levels of aggregation I present hereby the same data on the county level. Once the districts are aggregated to counties the number of observations falls to 200 .

Table 1 presents the summary statistics for the average hourly earnings of the employed population between 18 and 60 years of age at district and county levels. The average hourly wage varies from 9 pounds in 1998 to 11 pounds in 2003. Workers in rich regions receive almost three times higher wages compared to those in poor regions, a fact that confirms the importance of spatial differences in income across UK districts and counties. These characteristics of the hourly earnings at county level are very similar to those displayed by Rice and Venables (2004).

\footnotetext{
${ }^{12}$ NQV4 - first and higher degree; nursing and teaching qualification; NQV3 - A-level; GNVQ Higher level, Advanced certificate of Vocational Education; NVQ2 - GCSE qualifications at grade B or higher, GNVQ Intermediate level; NVQ1 - GSCE qualifications below grade C, GNVQ Foundation level.
} 
Table 1. Average Hourly Earnings (in British Pounds)

\begin{tabular}{lcccc}
\hline & \multicolumn{2}{c}{ Districts } & \multicolumn{2}{c}{ Counties } \\
\cline { 2 - 5 } & $\begin{array}{c}\text { Average Hourly } \\
\text { Earnings 1998 }\end{array}$ & $\begin{array}{c}\text { Average Hourly } \\
\text { Earnings 2003 }\end{array}$ & $\begin{array}{c}\text { Average Hourly } \\
\text { Earnings 1998 }\end{array}$ & $\begin{array}{c}\text { Average Hourly } \\
\text { Earnings 2003 }\end{array}$ \\
\hline Mean & 9.45 & 11.31 & 9.58 & 11.41 \\
Variance & 2.25 & 4.06 & 2.43 & 4.46 \\
Coefficient of Variation & 0.16 & 0.18 & 0.16 & 0.18 \\
Minimum & 6.72 & 8.28 & 7.57 & 8.95 \\
Maximum & 16.4 & 21.43 & 16.4 & 21.43 \\
Number of Observation & 304 & 304 & 200 & 200 \\
\hline
\end{tabular}

Employment density or agglomeration, which potentially explains a large part of these earnings' inequalities, is the other variable to exhibit substantial variation across regions. Table 2 shows the main characteristics of the agglomeration where the magnitude of the coefficient of variation takes values of 1.3 up to 1.48 and indicates large employment diversity across districts and counties with an increasing share of people employed per square kilometer over time.

Table 2. Employment Density (number of full-time employees per square km.)

\begin{tabular}{lcccc}
\hline & \multicolumn{2}{c}{ Districts } & \multicolumn{2}{c}{ Counties } \\
\cline { 2 - 5 } & Empl. & Empl. Density & Empl. Density & Empl. Density \\
& Density 1998 & 2003 & 1998 & 2003 \\
\hline Mean & 592.19 & 611.12 & 800.01 & 828.80 \\
Variance & 729024.3 & 813031.4 & 1075032 & 1198368 \\
Coefficient of Variation & 1.44 & 1.48 & 1.30 & 1.32 \\
Minimum & 2.87 & 3.19 & 2.87 & 3.19 \\
Maximum & 5166.67 & 6000 & 5166.67 & 6000 \\
Number of Observations & 304 & 304 & 200 & 200 \\
\hline
\end{tabular}


Fig.1. The Wage-Agglomeration Relationship

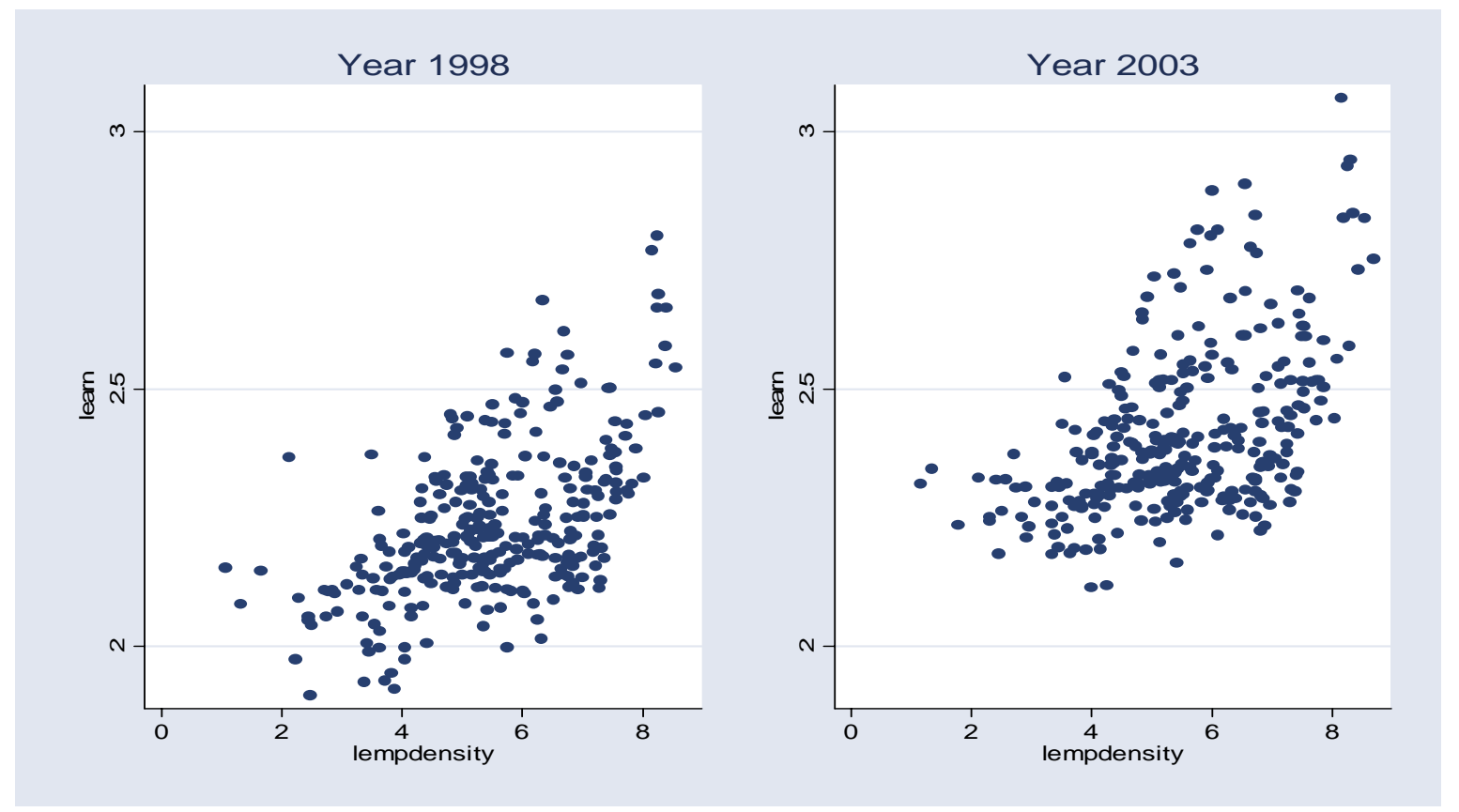

Evidence of the positive upward trend of the relationship between agglomeration and earnings across regions is provided by the above figure, which is based on raw data for hourly earnings and employment density across NUTS 4 districts for the years 1998 and 2003.

\section{Estimation Results}

In this section I account for the effect of agglomeration on average wages across regions in Great Britain. Firstly, table 3 and table 4 present the results of three different OLS specifications at both district and county level for the years 1998 and 2003. Looking at the district level results in both tables, specification 1 considers the pure effect of 
agglomeration on the average regional earnings. Specification 2 controls also for large region dummies ${ }^{13}$, gender and age (counties, which represent the next aggregation level), and specification 3 provides the richest equation offered by Ciccone (2002) where the corresponding proportion of workers at a certain education level plays a role in explaining regional wage inequalities. There is a strong positive relationship between the average proportion of workers with high education and the corresponding average regional earnings. Yet, regardless of the employed specification, the elasticity of hourly earnings with respect to employment density is around 0.04 for both years. ${ }^{14}$ The results reported here confirm the findings of existing studies (e.g., Ciccone, 2002; Rice and Venables, 2004) and demonstrate a robust OLS relationship between agglomeration and average labour income.

Next, the aggregation of the regional data to the next geographic level, i.e. county level, is performed with the main goal of comparing the results at district and county levels. Since there is no theoretically defined optimal level of examining the agglomeration effects, it is useful to see whether these effects are similar at different geography levels. Tables 3 and 4 present the OLS estimates at county level, which suggest no major difference in agglomeration related to the level of aggregation. The coefficient of agglomeration falls from 0.04 (district level) to 0.03 (county level) for both years based on the richest

\footnotetext{
${ }^{13}$ There are 11 large regions dummy variables: North East, North West, Yorkshire and the Humber; East Midlands, West Midlands, East, London, South East, South West, Scotland and Wales.

${ }^{14}$ The agglomeration effects were confirmed to be 0.06 at large regions' aggregation level though the result is not statistically meaningful due to the low number of degrees of freedom.
} 
specification. It appears that agglomeration effects do not depend on whether the geographical unit of analysis is district or county.

When studying agglomeration (employment density), it is natural to expect that big metropolitan cities exhibit higher level of employment density than the rest of the regions due to their population density. Metropolitan areas are known to have high population densities (London in particular), a fact which leads to the question whether the agglomeration effects on wages are not mainly driven by London and other big metropolitan cities. Therefore, I split the sample into two groups - Metropolitan and nonMetropolitan areas. ${ }^{15}$ In the case of Great Britain, Metropolitan areas consist of 71 districts. $^{16}$

Tables 5 and 6 show the OLS regression results at district and county levels for all three samples: the whole sample, the Metropolitan, and non-Metropolitan areas for the years 1998 and 2003. Overall, the tables show no difference between the OLS results at district and county levels. Focusing on the district level, we notice that for both years the coefficients of agglomeration for the whole sample and that for non-Metropolitan areas are the same. However, there is a significant difference in the magnitude of the agglomeration estimate for Metropolitan areas where the coefficient is 0.08 in 1998 and 0.09 in 2003 in comparison to 0.04 in the other two samples for both years. ${ }^{17}$ The effect of education is similar for all samples in that average wages are higher in areas with a higher proportion of

\footnotetext{
${ }^{15}$ The dummy variable for Metropolitan areas in the OLS specification of the whole sample is significant at the $1 \%$ significance level.

${ }^{16}$ Metropolitan areas include greater London, greater Manchester, Merseyside, South Yorkshire, Tyne and Wear, West Midlands, West Yorkshire, Glasgow city and Cardiff.
} 
workers with high education, and consequently lower if there is high proportion of workers with low education in the region. All specifications include dummy variables for the presence of large regions at the higher aggregation level.

The results suggest a new feature of the agglomeration-productivity relationship. While there is no significant difference between county and district level of aggregation, agglomeration effects soar in case of big densely populated Metropolitan areas. The high concentration of employees per unit of land seems to foster productivity growth. However, the presence of potential endogeneity between agglomeration and productivity may lead to different results and provide new insights on the mechanism of this relationship.

\section{Endogeneity}

In case regional dummy variables do not capture exogenous differences in incomes across regions, then areas with high exogenous incomes attract more workers and have subsequently higher employment density. As a result, OLS yields inconsistent estimates. The potential reverse causality between wage income and employment density calls for a different estimation approach involving instrumental variables.

\footnotetext{
17 The coefficient of agglomeration for Metropolitan areas is significantly different from those in nonMetropolitan areas and the whole sample at the $5 \%$ significance level.
} 
The instrumental-variables approach requires that valid instruments are applied. In this case, potential instruments are certain characteristics of districts that are correlated to agglomeration (employment density) but not correlated to the current incomes across regions. This analysis uses two instruments for agglomeration: the total land area of the region and the population density which dates back to 1801 . The total land area of the region is commonly used as an instrument for employment density in the literature (Ciccone, 2002; Ciccone and Hall, 1996). As Ciccone (2002) notes, the total land area of the region is historically predetermined and does not depend on the current productivity developments across regions. However, total land is significantly negatively correlated with employment density across districts which could be explained by the historical equalization of population size across districts. Another explanation for that negative relationship is through the price of land influenced by potentially better consumption amenities (Wheaton and Lewis, 2002; Combes et al., 2004) which make the agglomeration coefficient biased downwards. $^{18}$

The population density in 1801 is the second instrument for employment density (see Rice and Venables, 2004; Combes et al., 2004); it is positively correlated to agglomeration and not related to productivity or income across districts. This historic instrument reflects the way population was distributed in the past regardless of productivity incentives long before the industrial revolution took place in Great Britain.

\footnotetext{
${ }^{18}$ Better consumption amenities imply higher land prices which have negative effect on local wages. Since land prices are omitted from the regression equation, their negative effect enters the residual which is negatively correlated to employment density since better consumption amenities attract more workers in the region.
} 
Table 7 shows the two stage least squares estimation of agglomeration effects on average earnings in 2003 using the two instruments: the total land area of a region and the population density of a district in 1801 . Focusing on the full specification and accounting for both education and regional effects, I examine the instrumental estimation for all three samples. The tendency of agglomeration to have a larger impact on earnings in Metropolitan areas is preserved and the agglomeration coefficient falls from 0.09 in OLS to 0.08 when instrumented.

This fact confirms the hypothesis of potential endogeneity which appears also in nonMetropolitan areas. There the agglomeration effect decreases from 0.05 to 0.03 , once the instrumental-variables approach is applied. However, when looking at the results for the sample as a whole, the agglomeration coefficient increases from 0.04 to 0.05 , which casts doubts over the reverse causality between agglomeration and wages across regions, and calls for rigorous testing of endogeneity presence and instruments' validity. Comparing tables 6 and 7 suggests the same tendency at county level and therefore presented below are robustness checks of results at district level only. ${ }^{19}$

\section{Model tests}

The key to any instrumental-variable (IV) approach is to find valid instrumental variables which are exogenous (correctly excluded from the main equation) and which are not weak. In case the instruments are weak, then the presence of even slight correlation between the 
instruments and the error term in the original equation can lead to large inconsistencies of the IV estimates. The problem of 'weak instruments' arises either when the instruments are only weakly correlated with the endogenous regressor, or their number is too large (Angrist and Krueger, 2001). Once valid instruments are employed, the final step is to find out whether endogeneity is present in the first place (Hausman, 1978). In case of no evidence of endogenous relationship, the use of instrumental-variables approach becomes unnecessary.

Exogeneity of instruments is tested by regressing the endogenous variable on the potential instruments, which in this case should be correlated with employment density and not correlated with wages. The first two OLS specifications in table 8 present the results of testing the exogeneity of the two instruments at district level for 2003 . We can note from the table that the coefficients of both the total land area and the population density are significant at the $1 \%$ significance level in case agglomeration is the dependent variable, and they are not significantly different from zero when wages are estimated. Table 8 presents also specifications 3 and 4 where agglomeration is instrumented with only one instrument at a time, while the other instrument is included directly in the main equation (Card, 1993). We observe that in both cases the instrumental variables which are included directly in the main equation are not significant. Therefore, these two instruments are exogenous and are properly omitted from the initial regression equation.

\footnotetext{
${ }^{19}$ Model tests at county level are available upon request.
} 
In order to examine the assumption of whether the instruments are weak, a common approach is to look at the F-statistic for the joint significance of the instruments in the first stage equation (Bound et al., 1995). In case the F-statistic is larger than 10 the instruments are not considered to be weak (Staiger and Stock, 1997, Stock, Wright and Yogo, 2002). We can see from table 7 that the first stage F-statistics for the two instruments in use, are well above 10 for all the three samples under consideration, which shows that the instruments are jointly highly relevant and predict well the endogenous variable.

In case the endogenous variable is instrumented by more instruments, an over-identification test for the mutual consistence of the available instruments can be used. One of the most commonly applied tests is the Hansen (1982) / Sargan (1958) test, whose null hypothesis is that the excluded instruments are valid instruments and uncorrelated with the error term. ${ }^{20}$ The first row of table 9 shows the Hansen-Sargan statistic for all the samples under analysis and the p-values in the parenthesis which are 0.22 for the whole sample, 0.18 for the Metropolitan areas and 0.35 for non-Metropolitan areas show that we cannot reject the null hypothesis and therefore the instruments are jointly valid. However, there are studies that show that this test may have low power in case of general misspecification (e.g. Newey, 1985).

Hahn and Hausman (2002) developed a new overidentifing restriction test which takes a general specification approach and examines the relevance of the application of

\footnotetext{
${ }^{20}$ Under the null hypothesis the Hansen-Sargan statistics is distributed as chi-square in the number of overidentifying restrictions which are two in this case.
} 
conventional first order asymptotics. They claim that in the case of valid first order asymptotic inference, a change in normalization would yield similar forward and inverse coefficient estimates. Specifically, the forward (orthodox) two stage estimate of the coefficient of the right-hand side endogenous variable should be very similar to the inverse estimate from the reverse (the right hand side endogenous variables becomes the dependent variable and the dependent variable from the forward regression becomes the right-hand side variable) two stage regression using the same instruments. In case the two estimates are too different, the Hahn/Hausman test sees whether this difference in estimates satisfies the results of second order asymptotic theory.

Looking at the second and third rows of table 9 we see that the forward estimate for the whole sample is 0.05 while the inverse one is 0.052 , the Metropolitan areas forward estimate is 0.082 while the inverse one is 0.091 , and finally for non-Metropolitan areas the forward coefficient is 0.037 and in inverse one is 0.039 . The inverse estimates for all three samples are significant at the $1 \%$ significance level and are almost the same as the forward estimates, which proves that the first order asymptotics is relevant and the main equation is correctly specified.

Given that the instruments are valid, the last specification test is the Durbin-Wu-Hausman test, which is widely used in applied research to test the presence of endogeneity. The null hypothesis of that test is that the specification is proper and all the explanatory variables are exogenous. Table 9 shows that for the whole sample we reject the null hypothesis at the $1 \%$ significance level which means that there is no endogeneity problem. In case of 
Metropolitan areas endogeneity is present at the $10 \%$ significance level. The strongest case for endogenous relationship between agglomeration and wages across regions is the one for the non-Metropolitan areas where the p-value of 0.94 indicates endogeneity at the $1 \%$ significance level.

Overall, the use of the instrumental-variables approach is not justified for the whole sample since the agglomeration effects increase once employment density is instrumented by the total land area of the regions and the regional population density. Splitting the sample into Metropolitan and non-Metropolitan areas reveals the presence of endogeneity in the nonMetropolitan sample where agglomeration estimates fall from 0.05 to 0.03 . Metropolitan areas exhibit much higher agglomeration effects and not as strong endogenous relationship between the employment density and the incomes across regions, as non-Metropolitan areas, since the agglomeration coefficient is reduced by 1 percentage point and endogeneity is present only at the $10 \%$ significance level. The lower aggregation level (NUTS 4) enabled a detailed analysis of the endogeneity problem which appears to have new dimensions once Metropolitan cities are accounted for.

\section{Conclusion}

The main goal of this paper is to shed more light on the agglomeration effects on wages across districts of Great Britain. The empirical analysis for the two years of observation, 1998 and 2003, shows that there is a stable positive relationship between agglomeration as measured by employment density and the average earnings at the regional level. Doubling 
the agglomeration raises wages by $4 \%$ at both district and county level. Since counties are larger territorial units than districts and so capture agglomeration spillovers in-between districts, one may expect the agglomeration effects on productivity measured across counties to be higher than that estimated off district data. On the other hand, measuring wages and agglomeration at the county level may introduce measurement error as it may obscure important differences within counties. Hence, a possible explanation for the similar agglomeration-effect at county and district level is that these two opposing forces cancel each other.

Metropolitan areas are known for their high population (and employment) density and it is possible that the nature of the agglomeration-productivity relationship is different in major cities as opposed to non-metropolitan areas. Therefore, in the next step of the analysis I separately re-estimate the preferred specifications for the Metropolitan and nonMetropolitan sub-samples. While non-Metropolitan areas exhibit similar coefficients to those prevailing when the whole sample is under consideration, comparing wages and agglomeration within Metropolitan areas shows significantly higher agglomeration effects. The high concentration of employees per unit of land in Metropolitan areas seems to have a much stronger positive effect on productivity than the effect of employment density on productivity in non-Metropolitan areas.

A major possible weakness of the analysis stems from the potential presence of reverse causality between agglomeration and productivity, which could lead to biased estimates. Therefore, two stage least square instrumental-variables approach was employed in 
estimating the potentially endogenous relationship between wages and agglomeration. In contrast to existing studies, two instruments are used in the analysis: the total land area of the district and the population density of a district in 1801 . Both instruments proved to be valid and to explain agglomeration well. The instrumental-variable results confirm the OLS tendency of Metropolitan areas exhibiting the highest agglomeration effects on productivity though the estimates are slightly lower due to upward biasness of the original estimates. Reverse causality between agglomeration and productivity is stronger in the nonMetropolitan areas sample where the agglomeration effect decreases by 2 percentage points. These results prove even further that agglomeration has only modest impact on wages in non-Metropolitan areas in comparison to the effect it has across densely populated Metropolitan cities. 


\section{Bibliography}

Angrist, J. D. and G. W. Imbens (1995) "Two-Stage Least Squares Estimation of Average Causal Effects in Models with Variables Treatment Intensity", Journal of the American Statistical Association, 90 (430), 431-442.

Angrist, J. D. and A. Krueger (2001) "Instrumental Variables and the Search for Identification: From Supply and Demand to Natural Experiments", Journal of Economic Perspectives, 15 (4), 69-85.

Aten, B. and A. Heston (2003) "Regional Output Differences in International Perspective", Spatial Inequality and Development Conference Proceedings, (Cornel1/LSE/WIDER), London, forthcoming.

Blackaby, D. and P. Murphy (1995), "Earnings, Unemployment and Britain's North-South Divide: Real or Imaginary?", Oxford Bulletin of Economics and Statistics, Vol.57(4), 487-512.

Bound, J., Jaeger D. A. and R. M. Baker (1995) "Problem with Instrumental Variables Estimation when the Correlation between the Instruments and the Endogenous Explanatory Variable is Weak", Journal of the American Statistical Association, 90 (430), 443-450.

Card D. (1993), "Using Geographic Variation in College Proximity to Estimate the Return to Schooling", NBER, Working Paper No. 4483.

Ciccone, A. and R. E. Hall (1996) "Productivity and the Density of Economic Activity", American Economic Review, 86(1), 54-70.

Ciccone, A. (2002) "Agglomeration-Effects in Europe", European Economic Review, 46(2), 213-228.

Combes, P-P, G. Duranton and L. Gobillon (2004) "Spatial Wage Disparities: Sorting Matters!", CEPR, Discussion Paper Series, No. 4240.

Duranton, G. and V. Monastiriotis (2002) "Mind the Gaps: The Evolution of Regional Inequalities in the UK 1982-1997”, Journal of Regional Science, 42(2), 219-256.

Hahn, J. and J. Hausman (2002) "A New Specification Test for the Validity of Instrumental Variables”, Econometrica, 70, 163-189.

Hausman, J. A. (1978) "Specification Tests in Econometrics", Econometrica, 46 (6), 12511271.

Henderson, J. V. (1986) "Efficiency of Resource Usage and City Size", Journal of Urban Economics, 18, 47-60. 
Kanbur, R. and A. J. Venables (2005) "Introduction: Spatial Equality and Development", Journal of Economic Geography, Oxford University Press, 5(1), 1-2.

Monastiriotis, V. (2004) "Inter- and Intra-Regional Inequalities in the UK: An Examination of the Sources of the UK Wage Inequalities and Their Evolution", ERSA Conference Papers, ersa00, 228.

Moomaw, R. L. (1985) "Firm Location and City Size: Reduced Productivity Advantages as a Factor in the Decline of manufacturing in Urban Areas", Journal of Urban Economics, 17, 73-90.

Newey, W. (1985) "Generalized Method of Moments Specification Testing”, Journal of Econometrics, 29, 229-256.

Rice, P. and A. J. Venables (2004) "Spatial Determinants of Productivity: Analysis for the Regions of Great Britain”, CEPR, Discussion Paper Series, No. 4527.

Rosenthal, S. S. and W. C. Strange (2001) “The determinants of Agglomeration”, Journal of Urban Economics, 50, 191-229.

Rosenthal, S. S. and W. C. Strange (2004) "Evidence on the Nature and Sources of Agglomeration Economies", forthcoming in V. Henderson and J. Thisse, eds. Handbook of Urban and Regional Economics, Vol.4.

Staiger, D. and J. Stock (1997) "Instrumental Variables Regressions when Instruments are Weak”, Econometrica, 65, 557-586.

Stock, J., Wright, J. and M. Yogo (2002) "A Survey of Weak Instruments and Weak Identification in Generalized Method of Moments", Journal of Business and Economic Statistics, 20, 518-529.

Strange, W. C. (2003) "Agglomeration Economies and the Future of Cities", Policy Analysis and Economic Policy Conference.

Wheaton, W. C. and M. J. Lewis (2002) "Urban Wages and Labour market Agglomeration", Journal of Urban Economics, 51(3), 542-562. 
Table 3. OLS Estimates of the Effect of Agglomeration on Earnings: Districts vs. Counties (1998)

\begin{tabular}{|c|c|c|c|c|c|c|}
\hline & \multicolumn{3}{|c|}{$\begin{array}{c}\text { Districts } \\
\text { Average Earnings } 1998\end{array}$} & \multicolumn{3}{|c|}{$\begin{array}{c}\text { Counties } \\
\text { Average Earnings } 1998\end{array}$} \\
\hline & 1 & 2 & 3 & 4 & 5 & 6 \\
\hline Agglomeration & $\begin{array}{l}0.055^{* * *} \\
(0.005)\end{array}$ & $\begin{array}{l}0.044^{* * *} \\
(0.006)\end{array}$ & $\begin{array}{l}0.037^{* * *} \\
(0.006)\end{array}$ & $\begin{array}{l}0.053^{* * *} \\
(0.006)\end{array}$ & $\begin{array}{l}0.041^{* * *} \\
(0.006)\end{array}$ & $\begin{array}{l}0.032^{* * *} \\
(0.006)\end{array}$ \\
\hline High Education $^{a}$ & No & No & $\begin{array}{l}0.171^{* * *} \\
(0.044)\end{array}$ & No & No & $\begin{array}{l}0.194^{* * *} \\
(0.043)\end{array}$ \\
\hline Low Education & No & No & $\begin{array}{c}-0.113^{* * *} \\
(0.051)\end{array}$ & No & No & $\begin{array}{l}-0.060 \\
(0.047)\end{array}$ \\
\hline $\begin{array}{l}\text { Regional Dummies and } \\
\text { other control variables }\end{array}$ & No & Yes & Yes & No & Yes & Yes \\
\hline $\mathrm{R}^{2}$ & 0.30 & 0.51 & 0.60 & 0.34 & 0.56 & 0.68 \\
\hline Number of Observations & 304 & 301 & 202 & 200 & 199 & 151 \\
\hline
\end{tabular}


Table 4. OLS Estimates of the Effect of Agglomeration on Earnings: Districts vs. Counties (2003)

\begin{tabular}{|c|c|c|c|c|c|c|}
\hline & \multicolumn{3}{|c|}{$\begin{array}{c}\text { Districts } \\
\text { Average Earnings } 2003\end{array}$} & \multicolumn{3}{|c|}{$\begin{array}{c}\text { Counties } \\
\text { Average Earnings } 2003\end{array}$} \\
\hline & 1 & 2 & 3 & 4 & 5 & 6 \\
\hline Agglomeration & $\begin{array}{l}0.054^{* * *} \\
(0.006)\end{array}$ & $\begin{array}{l}0.047^{* * *} \\
(0.006)\end{array}$ & $\begin{array}{l}0.041^{* * *} \\
(0.007)\end{array}$ & $\begin{array}{l}0.054^{* * *} \\
(0.006)\end{array}$ & $\begin{array}{l}0.042^{* * *} \\
(0.007)\end{array}$ & $\begin{array}{l}0.029^{* * *} \\
(0.007)\end{array}$ \\
\hline High Education $^{a}$ & No & No & $\begin{array}{l}0.197^{* * *} \\
(0.061)\end{array}$ & No & No & $\begin{array}{l}0.186^{* * *} \\
(0.070)\end{array}$ \\
\hline Low Education & No & No & $\begin{array}{c}-0.132^{* * *} \\
(0.049)\end{array}$ & No & No & $\begin{array}{c}-0.142^{* * *} \\
(0.044)\end{array}$ \\
\hline $\begin{array}{l}\text { Regional Dummies and } \\
\text { other control variables }\end{array}$ & No & Yes & Yes & No & Yes & Yes \\
\hline $\mathrm{R}^{2}$ & 0.25 & 0.46 & 0.55 & 0.30 & 0.52 & 0.64 \\
\hline Number of Observations & 304 & 302 & 231 & 200 & 198 & 175 \\
\hline
\end{tabular}


Table 5. The Effect of Agglomeration on Earnings at district and county level (1998)

\begin{tabular}{|c|c|c|c|c|c|c|}
\hline & \multicolumn{3}{|c|}{ Districts } & \multicolumn{3}{|c|}{ Counties } \\
\hline & $\begin{array}{c}1 \\
\text { OLS: } \\
\text { Whole Sample }\end{array}$ & $\begin{array}{c}2 \\
\text { OLS: } \\
\text { MetroCities }\end{array}$ & $\begin{array}{c}3 \\
\text { OLS: } \\
\text { No-MetroCities } \\
\end{array}$ & $\begin{array}{c}4 \\
\text { OLS: } \\
\text { Whole Sample }\end{array}$ & $\begin{array}{c}5 \\
\text { OLS: } \\
\text { MetroCities }\end{array}$ & $\begin{array}{c}6 \\
\text { OLS: } \\
\text { No-MetroCities }\end{array}$ \\
\hline Agglomeration & $\begin{array}{l}0.037^{* * *} \\
(0.006)\end{array}$ & $\begin{array}{l}0.084^{* * *} \\
(0.026)\end{array}$ & $\begin{array}{l}0.039^{* * *} \\
(0.006)\end{array}$ & $\begin{array}{l}0.032^{* * *} \\
(0.006)\end{array}$ & $\begin{array}{c}0.094^{* * *} \\
(0.028)\end{array}$ & $\begin{array}{l}0.033^{* * *} \\
(0.007)\end{array}$ \\
\hline High Education & $\begin{array}{l}0.171^{* * *} \\
(0.044)\end{array}$ & $\begin{array}{l}0.137^{* *} \\
(0.063)\end{array}$ & $\begin{array}{l}0.197^{* * *} \\
(0.056)\end{array}$ & $\begin{array}{l}0.194^{* * *} \\
(0.043)\end{array}$ & $\begin{array}{l}0.181^{* *} \\
(0.078)\end{array}$ & $\begin{array}{l}0.207^{* * *} \\
(0.051)\end{array}$ \\
\hline Low Education & $\begin{array}{l}-0.113^{* * *} \\
(0.051)\end{array}$ & $\begin{array}{l}-0.139 \\
(0.117)\end{array}$ & $\begin{array}{l}-0.078 \\
(0.059)\end{array}$ & $\begin{array}{l}-0.060 \\
(0.047)\end{array}$ & $\begin{array}{l}-0.070 \\
(0.102)\end{array}$ & $\begin{array}{l}-0.055 \\
(0.045)\end{array}$ \\
\hline $\begin{array}{l}\text { Regional Dummies and } \\
\text { other control variables }\end{array}$ & Yes & Yes & Yes & Yes & Yes & Yes \\
\hline$R^{2}$ & 0.60 & 0.60 & 0.58 & 0.68 & 0.65 & 0.59 \\
\hline $\begin{array}{l}\text { Number of } \\
\text { Observations }\end{array}$ & 202 & 65 & 137 & 151 & 65 & 86 \\
\hline
\end{tabular}


Table 6. The Effect of Agglomeration on Earnings at district and county level (2003)

\begin{tabular}{|c|c|c|c|c|c|c|}
\hline & $\begin{array}{c}1 \\
\text { OLS: } \\
\text { Whole Sample }\end{array}$ & $\begin{array}{c}2 \\
\text { OLS: } \\
\text { MetroCities }\end{array}$ & $\begin{array}{c}3 \\
\text { OLS: } \\
\text { No-MetroCities }\end{array}$ & $\begin{array}{c}4 \\
\text { OLS: } \\
\text { Whole Sample } \\
\end{array}$ & $\begin{array}{c}5 \\
\text { OLS: } \\
\text { MetroCities }\end{array}$ & $\begin{array}{c}6 \\
\text { OLS: } \\
\text { No-MetroCities }\end{array}$ \\
\hline Agglomeration & $\begin{array}{l}0.041^{* * *} \\
(0.007)\end{array}$ & $\begin{array}{l}0.091^{* * *} \\
(0.03)\end{array}$ & $\begin{array}{l}0.051^{* * *} \\
(0.007)\end{array}$ & $\begin{array}{l}0.029^{* * *} \\
(0.007)\end{array}$ & $\begin{array}{l}0.091^{* * *} \\
(0.025)\end{array}$ & $\begin{array}{l}0.032^{* * *} \\
(0.007)\end{array}$ \\
\hline High Education & $\begin{array}{l}0.197^{* * *} \\
(0.061)\end{array}$ & $\begin{array}{l}0.123^{* * *} \\
(0.056)\end{array}$ & $\begin{array}{l}0.238^{* * *} \\
(0.053)\end{array}$ & $\begin{array}{l}0.186^{* * *} \\
(0.070)\end{array}$ & $\begin{array}{l}0.124^{* * *} \\
(0.006)\end{array}$ & $\begin{array}{l}0.208^{* * *} \\
(0.061)\end{array}$ \\
\hline Low Education & $\begin{array}{l}-0.132^{* * *} \\
(0.049)\end{array}$ & $\begin{array}{l}-0.281^{* * *} \\
(0.072)\end{array}$ & $\begin{array}{l}-0.017 \\
(0.053)\end{array}$ & $\begin{array}{l}-0.142^{* * *} \\
(0.044)\end{array}$ & $\begin{array}{l}-0.203^{* * *} \\
(0.072)\end{array}$ & $\begin{array}{l}-0.055 \\
(0.045)\end{array}$ \\
\hline $\begin{array}{l}\text { Regional Dummies and } \\
\text { other control variables }\end{array}$ & Yes & Yes & Yes & Yes & Yes & Yes \\
\hline $\mathrm{R}^{2}$ & 0.55 & 0.62 & 0.50 & 0.64 & 0.62 & 0.59 \\
\hline $\begin{array}{l}\text { Number of } \\
\text { Observations }\end{array}$ & 231 & 68 & 163 & 175 & 68 & 107 \\
\hline
\end{tabular}

Note: Huber-White standard errors are in parentheses. $* * *$ denotes significance at the 1 percent significance level,; $* *$ denotes significance at the 5 percent significance level; * denotes significance at the 10 percent significance level. The coefficient of agglomeration in (2) is significantly different from the one in (3) at the $5 \%$ significance level. 
Table 7. The Effect of Agglomeration on Earnings using Population Density 1801 and Area as Instruments (2003)

\begin{tabular}{|c|c|c|c|c|c|c|}
\hline & \multicolumn{3}{|c|}{ Districts } & \multicolumn{3}{|c|}{ Counties } \\
\hline & $\begin{array}{c}1 \\
\text { IV: } \\
\text { Whole Sample }\end{array}$ & $\begin{array}{c}2 \\
\text { IV: } \\
\text { MetroCities }\end{array}$ & $\begin{array}{c}3 \\
\text { IV: } \\
\text { No-MetroCities }\end{array}$ & $\begin{array}{c}4 \\
\text { IV: } \\
\text { Whole Sample }\end{array}$ & $\begin{array}{c}5 \\
\text { IV: } \\
\text { MetroCities } \\
\end{array}$ & $\begin{array}{c}6 \\
\text { IV: } \\
\text { No-MetroCities }\end{array}$ \\
\hline Agglomeration & $\begin{array}{l}0.050^{* * *} \\
(0.010)\end{array}$ & $\begin{array}{l}0.082^{* * *} \\
(0.023)\end{array}$ & $\begin{array}{l}0.033^{* * *} \\
(0.010)\end{array}$ & $\begin{array}{c}0.043^{* * *} \\
(0.015)\end{array}$ & $\begin{array}{l}0.084^{* * *} \\
(0.023)\end{array}$ & $\begin{array}{l}0.022^{* * *} \\
(0.011)\end{array}$ \\
\hline High Education & $\begin{array}{l}0.189^{* * *} \\
(0.061)\end{array}$ & $\begin{array}{l}0.142^{* * *} \\
(0.085)\end{array}$ & $\begin{array}{l}0.244^{* * *} \\
(0.056)\end{array}$ & $\begin{array}{l}0.156^{* * *} \\
(0.075)\end{array}$ & $\begin{array}{l}0.153^{* * *} \\
(0.085)\end{array}$ & $\begin{array}{l}0.213^{* * *} \\
(0.066)\end{array}$ \\
\hline Low Education & $\begin{array}{l}-0.135^{* * *} \\
(0.049)\end{array}$ & $\begin{array}{c}-0.287^{* * *} \\
(0.075)\end{array}$ & $\begin{array}{l}-0.024 \\
(0.055)\end{array}$ & $\begin{array}{c}-0.159^{* * *} \\
(0.048)\end{array}$ & $\begin{array}{c}-0.291^{* * *} \\
(0.075)\end{array}$ & $\begin{array}{l}-0.049 \\
(0.046)\end{array}$ \\
\hline $\begin{array}{l}\text { Regional Dummies and } \\
\text { other control variables }\end{array}$ & Yes & Yes & Yes & Yes & Yes & Yes \\
\hline $\begin{array}{l}\text { First-stage F-statistic for } \\
\text { both instruments }\end{array}$ & 128.36 & 70.57 & 53.21 & 183.84 & 71.01 & 84.25 \\
\hline$R^{2}$ & 0.55 & 0.61 & 0.49 & 0.63 & 0.61 & 0.59 \\
\hline Number of Observations & 231 & 68 & 163 & 175 & 68 & 107 \\
\hline
\end{tabular}


Table 8. Reduced Form and Structural Estimates of the Earnings and Agglomeration Models (year 2003)

\begin{tabular}{|c|c|c|c|c|}
\hline & $\begin{array}{c}1 \\
\text { Agglomeration } \\
\text { OLS }\end{array}$ & $\begin{array}{c}2 \\
\text { Earnings } \\
\text { OLS }\end{array}$ & $\begin{array}{c}3 \\
\text { Earnings } \\
\text { 2STLS } \\
\end{array}$ & $\begin{array}{c}4 \\
\text { Earnings } \\
\text { 2STLS }\end{array}$ \\
\hline Population Density 1801 & $\begin{array}{l}0.66^{* * *} \\
(0.08)\end{array}$ & $\begin{array}{c}0.05 \\
(0.08)\end{array}$ & $\begin{array}{c}0.03 \\
(0.05)\end{array}$ & ----- \\
\hline Area & $\begin{array}{l}-0.02^{* * *} \\
(0.01)\end{array}$ & $\begin{array}{l}-0.00005 \\
(0.00006)\end{array}$ & ---- & $\begin{array}{c}0.003 \\
(0.008)\end{array}$ \\
\hline $\begin{array}{l}\text { Regional Dummies and other } \\
\text { control variables }\end{array}$ & Yes & Yes & Yes & Yes \\
\hline$R^{2}$ & 0.66 & 0.44 & 0.55 & 0.50 \\
\hline Number of Observations & 302 & 302 & 231 & 231 \\
\hline
\end{tabular}

Note: Huber-White standard errors are in parentheses. *** denotes significance at 1 percent significance level; ** denotes significance at 5 percent significance level; $*$ denotes significance at 10 percent significance level. 
Table 9. Over-identifying Restrictions and Endogeneity Tests

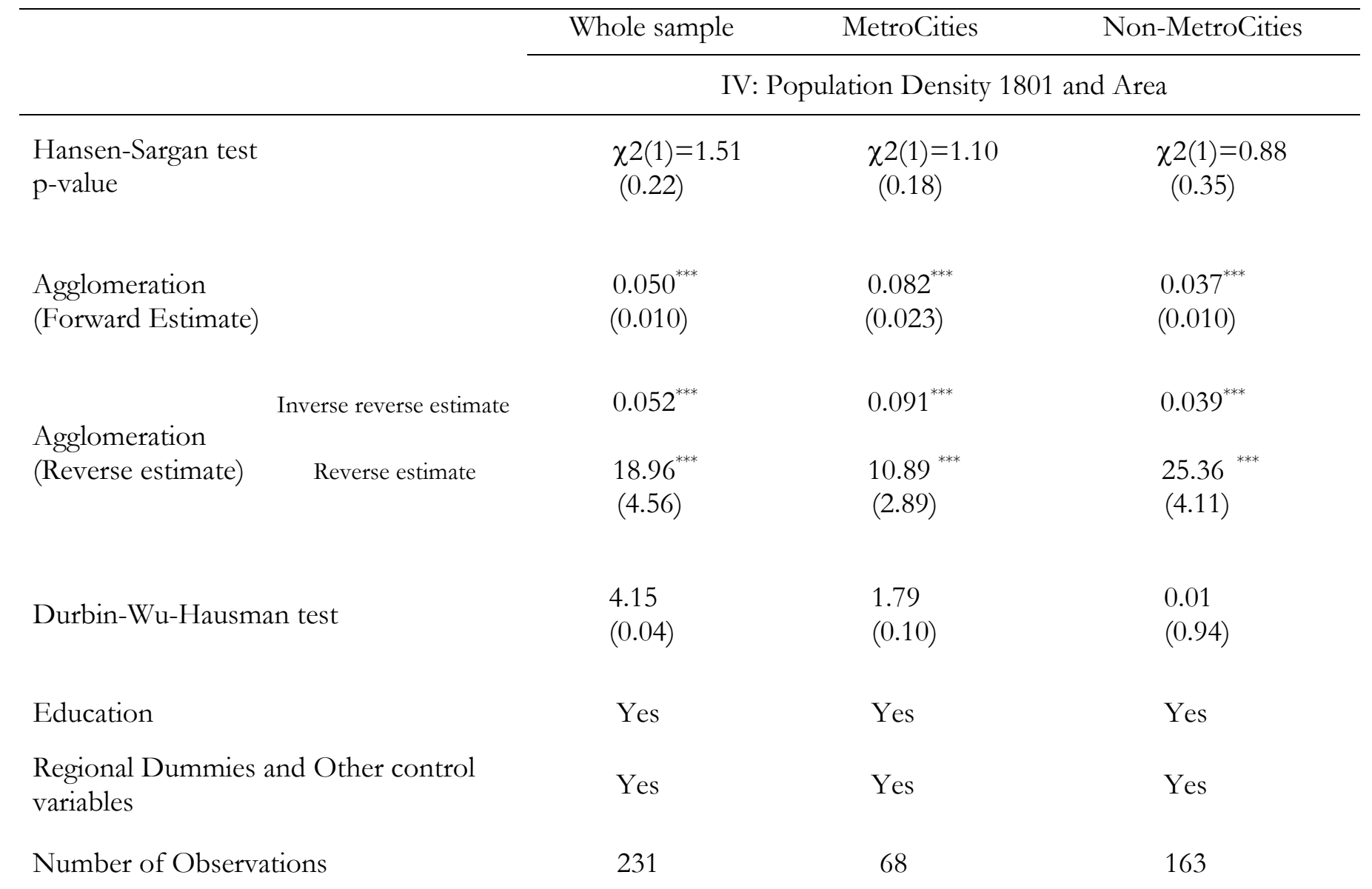

Note $* * *$ denotes significance at 1 percent significance level. Standard errors are in parentheses with the exception of Hansen-Sargan test and Durbin-Wu-Hausman test where p-values are reported in the parentheses. 
Individual researchers, as well as the on-line and printed versions of the CERGE-EI Working Papers (including their dissemination) were supported from the following institutional grants:

- Center of Advanced Political Economy Research [Centrum pro pokročilá politicko-ekonomická studia], No. LC542, (2005-2009),

- Economic Aspects of EU and EMU Entry [Ekonomické aspekty vstupu do Evropské unie a Evropské měnové unie], No. AVOZ70850503, (2005-2010);

- Economic Impact of European Integration on the Czech Republic [Ekonomické dopady evropské integrace na ČR], No. MSM0021620846, (2005-2011);

Specific research support and/or other grants the researchers/publications benefited from are acknowledged at the beginning of the Paper.

(c) Lubomira Anastassova, 2006

All rights reserved. No part of this publication may be reproduced, stored in a retrieval system or transmitted in any form or by any means, electronic, mechanical or photocopying, recording, or otherwise without the prior permission of the publisher.

Published by

Charles University in Prague, Center for Economic Research and Graduate Education (CERGE) and

Economics Institute (EI), Academy of Sciences of the Czech Republic

CERGE-El, Politických vězňů 7, 11121 Prague 1, tel.: +420 224005 153, Czech Republic.

Printed by CERGE-EI, Prague

Subscription: CERGE-EI homepage: http://www.cerge-ei.cz

Editors: Directors of CERGE and EI

Managing editors: Deputy Directors for Research of CERGE and EI

ISSN 1211-3298

ISBN 80-7343-084-3 (Univerzita Karlova v Praze, CERGE)

ISBN 80-7344-073-3 (Národohospodářský ústav AV ČR, Praha) 
CERGE-EI

P.O.BOX 882

Politických vězňů 7

11121 Praha 1

Czech Republic http://www.cerge-ei.cz 